\title{
The Influence of Gadget on Wards Social Interaction of Adolescents at SMK Gunung Sari 1 Makassar \\ Musaidah ${ }^{1}$ \\ 1 Program Studi Sarjana Stikper Gunung Sari Makassar, Indonesia correspondent: Musaidahidah@yahoo.com \\ DOI: http:// doi.org/10.29080/jhsp.v3i3S.296
}

\begin{tabular}{ll}
\hline Keywords & Abstract \\
\hline $\begin{array}{l}\text { Intensity; } \\
\text { communication; } \\
\text { addiction; } \\
\text { social } \\
\text { interaction }\end{array}$ & $\begin{array}{l}\text { Social interaction denotes adaptation with surroundings between individual and } \\
\text { individual, individuals and groups, and groups and groups. The purpose of this } \\
\text { research is to know the influence of gadget towards the social interaction of juveniles } \\
\text { at SMK Gunung Sari } 1 \text { Makassar. The type of this research is quantitative descriptive } \\
\text { using Simple Random Sampling with the number of } 41 \text { samples which means that the } \\
\text { analysis of scientific method used number starting from data collection, data } \\
\text { interpretation and its result. The purpose of this is to know the influence of } \\
\text { independent variable, gadget (the intensity of use, communication and online game } \\
\text { wich correlation wards dependent variable (social interaction of teenagers). Based on } \\
\text { the statistical test by using Correlation test in this analysis used is the correlation with } \\
\text { ameaning } \alpha=0.05 \text { an confidence interval, the intensity of gadget use was obtained by } \\
\text { the value of p = 0.000 with the value of } r=0.615 \text { which means that the result of the } \\
\text { hypothesis mentioned that there was an effect of the intensity of the gadget use } \\
\text { towards the social interaction of adolescents with moderate relationship and positive } \\
\text { direction (unidirectional). The variable gadget as the means of communication to the } \\
\text { variable of online game addiction obtained a value of p=0.000 with r=0.689. Thus, } \\
\text { there is an influence of online game towards the social interaction of juveniles with } \\
\text { strong relationships and unidirectional }\end{array}$ \\
\end{tabular}

\section{Introduction}

The significant development of technology has made everything more accessible and instant. This certainly brings not only positive impacts but also negative impacts. One of the of technology advancement has been found in the lack of social interaction between people since they prefer to keep in touch with the improvement of technological tools. Their interest in those tools has set social interaction away, in other words, it has risen the of social values. The human interaction has been slowly replaced by their gadgets due to the fact that more people would rather spend their time with their screen than do intercommunication (1).

Based on the report of We Are Social,GSMA Intelligence stated that tere was an increasing number of gadget users about 43 millions which showed 1\% rising in the last three months in January 2017. Moving into the forth month, April 2017, the users of the gadget depicted considerable leap 5 or 4.96 billion meaning that three-quarter of world population has possessed gadget(2).

The survey of Nielsen reported that smartphone users have predominantly come from adolescents in the United States. This category of users showed a sharper growth than the adult users. Precisely, $58 \%$ of 14 to 17 of teenagers have used smartphone. This percentage has increased to $36 \%$ compared to previous data on July 2017. The increasing number of smartphone users among teenagers in the USA is quite surprising regarding with the unnecessary function for their activities (3).

Research institution of digital marketing, e-marketer pointed out that the user of the in Indonesia has depicted gradual increase annually. For example, the number of smartphone reached 27,4 millions of users in 2013, 38,3 millions of users in 2014, 52,2 million users in $2015,69,4$ million users in 2016, and 86,6 million users in 2017 until it is predicted that in 2018 the number of smartphone users would reach more than 100 millions(4).

In the USA, as many as 1.500 .000 parents informed that their children suffered emotional problem 
and development and consistent behavior. Besides, $12.5 \%$ children in Singapore experienced emotional turbulence which is a social interaction trouble (5).

It was founded that people used up their time to access their smartphones without any urgent concern. True, the tools are used for multiple purposes, specifically, for long-distance communication when people can make an indirect meeting. But along with the development of technology, the inventors have been developing a variety of features that enaable to facilitate not only intercommunication but also selfactualization with social media, such as Facebook, twitter, Instagram, and path. Besides, the gadget is in use for entertaining purpose since people manage to play games and log into YouTube for reducing stress. Unfortunately, the gadget has met with out-of-control use either its time or location. Initially, the gadget was used for simplifying the individuals communication but on the contrary, people spend more their time with their technological tools rather than socialize with their family. This uncontrolled use of gadget can cause the problem of social interaction (6).

SMK Gunung Sari 1 Makassar is a vocational school providing varied expertises. In this research, 70 students from grade XI and XII class were the research subject. Based on the interview, it was found that all students have smartphone. When the researcher conducted the interview in the class, the majority of students logged in their social media or played game. In the same time, the researcher found that some students kept playing their gadget while some of them rejected the photo invitation. When conducting observation in the break time, some students stayed alone by playing game.

Next, it was found that students side by side playing game without any friendly talk. When interview was conducted, they mentioned that they preferred playing game due to its entertaining features to having conversation with their friends-they. Could not go away from their gadget. Furthermore, when the teacher explained the subject, the students tended to play game in the classroom rather than pay attention on their teacher's explanation. This is due to the fact that the school did not make a policy regarding with bringing smartphone in the classroom.

\section{Methods}

The researcher used quantitative descriptive with sample random sampling, a method of scientific analysis using number for data collection, data interpretation and the results. The purpose is to know the influence of independent variable (gadget, online game addiction) to dependent variable (social interaction of teenagers). This research was conducted at SMK Gunung Sari Makassar from April to June 2018. The number of population was 70 students taken from students X and XI grade possessing gadget. In selecting sample, the researcher used simple random sampling technique in which the researcher gave opportunity to population member to be chosen as sample. Bivariate analysis used Correlation test with significance rate used by the researcher was 95 .

\section{Results}

1. Characteristics of Respondents

Table 1 Distribution of Respondentsbased on the years

\begin{tabular}{cccc}
\hline No & Age & $\begin{array}{c}\text { Number } \\
(\mathrm{n})\end{array}$ & Percentage \\
\hline 1 & $15-17$ & 31 & 75,6 \\
2 & $18-20$ & 10 & 24,4 \\
& Total & 41 & 100,0 \\
\hline
\end{tabular}

Source Primary Data, 18 July 2018

There were 31 students coming from the-17 age category, while only 10 or $24.4 \%$ from the group age of 18 20..It could be seen from table 5.3, 38 out of 41respondents were males, while 3 were females. This big difference existed because of the majority of students at SMK Gunung Sari 1 Makassar were male.

Table 2. Distribution of Respondentsbased on the Type of Gadget

\begin{tabular}{llll}
\hline No & Gadget & $\begin{array}{l}\text { Number } \\
(\mathrm{n})\end{array}$ & Percentage \\
\hline 1 & Used & 38 & 92.7 \\
2 & Smartphone & 3 & 7.3 \\
& Laptop/ Notebook & 41 & 100 \\
\hline
\end{tabular}

Source: Primary Data, 18 July 2018 
Table 2 depicted that out of 41 respondents, 38 students or $92.7 \%$ used smartphone, while only 3 or $7.3 \%$ used laptop or Notebook, meaning Smart Phone became the most used hardware by students. This is because due to is overused is more portable than laptop. Besides, people can access many interesting features in the smartphone that were just set on laptops. the number of students from class X was 17 out of 41 (41.5\%) while 24 (58.5\%) from class XI.

2. Univariate Analysis

Table 3 Distribution of Game Online Addiction

\begin{tabular}{cccc}
\hline No & Online Game Addiction & Number (n) & Percentage \\
\hline 1. & Not addictive & 16 & 39 \\
& & & 61 \\
2. & Addictive & 25 & 100 \\
\hline
\end{tabular}

Source: Primary Data, 18 July 2018

Table 3 informed that $61 \%$ of the students experience addiction of online game while $39 \%$ was not. Therefore, the students prone to be addictive because their interest in online game continously grow,furthermore, its easiness made the students difficult to control their play time.depictedthe social interaction of the students. To be more precise, the students who had good social engagement were 13 or $31.7 \%$ while 28 or $68.3 \%$ students presented poor social interaction. It can be concluded that those spending more time with their gadget tend to have deficient social attitude.

3. Bivariate Analysis

Table 4 Correlation of Game OnlineAddiction Towards Social Interaction

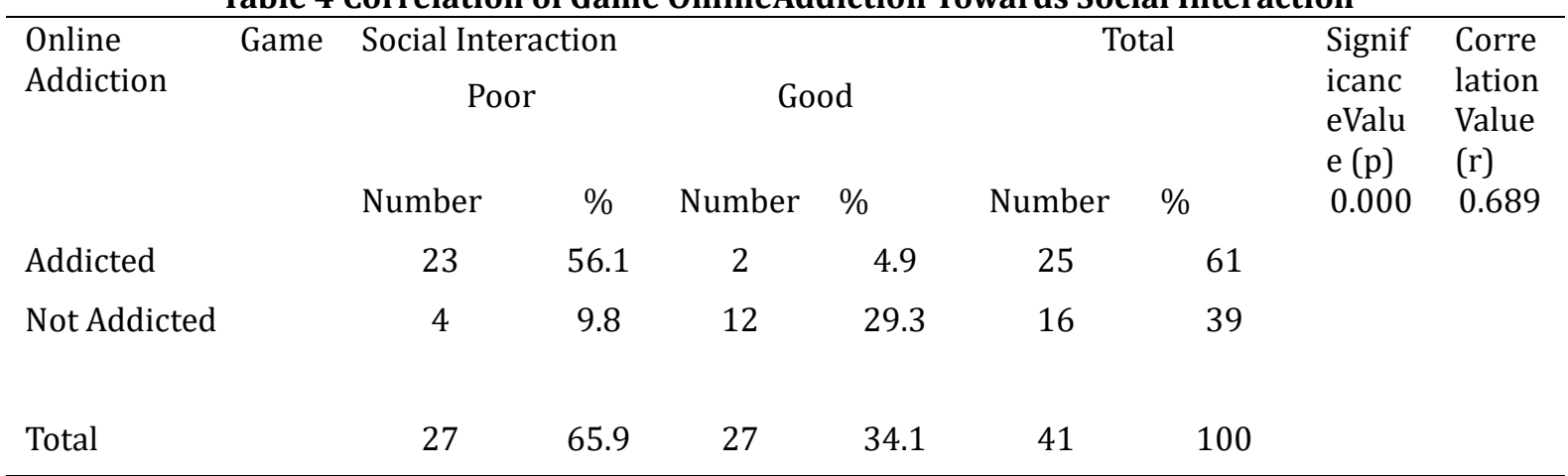

Source: Primary Data, July 18, 2018

Table 4 presented that significance $(p)$ was 0.000 , in which $p(0.000)<\alpha(0.05)$. It means that there is a significant influence of online game addiction by gadget on social interaction. By the correlation test, it was earned that $(r)=0.689$ which meant that addiction to online game by gadget contribute $68.9 \%$ to social interaction of respondents. Thus, it could be concluded that game online addiction brings impact on social interaction of students with strong relation and unidirectional. In other words, the higher addiction of students towards game online through gadget, the lower the direct or indirect social interaction they make.

\section{Discussion}

Based the Correlation test, $\mathrm{p}=0 / 006$ with significance $<0,05$ meaning that Ha accepted while Ho rejected. Thus, there was a significant influence the online game addiction by the gadget on social interaction. The result showed that there is a strong relation with the positive direction supported by data. To be precisely, out of 41 respondents experiencing addiction, 23 students (56.1\%) had poor social adaptation while only 2 or $4.9 \%$ students did good adaptability. Meanwhile, 4 (9.8\%) performed poor social engagement, while 12 (29.3\%) presented positive attitude out of 45 respondents.

It could be seen from the research that all respondents addicted to online game had poor social interaction while those not addicted almost had good social adaptation, even though, some of them also had less social interaction. This is probably because of the intensity of using gadget to communicate or unexplained factors on this research. It is supported by a theory stating that online game brings about 
negative impacts on social adaptability which could drive psychological and social problem.

One of the causes of bad social adaptation is because people do not find appropriate way to solve conflict from their surroundings as a result of their prolonged frustration. People in addiction will stay focusing on their online game and feel anxiety when they do not play it. Furthermore, they will enjoy spending time with game online that will bring downsides to their social interaction (7).

The researcher found that the addiction to online game will significantly influence the social interaction of society after it has become the primary importance of some people. This social problem must be addressed because it correlates with psychology and mentality of people. Moreover, game online has been played by multiple ages including male adolescents who can play it easily

This is in accordance with the theory which says that the intensity of the use of gadgets can make the value of social interaction diminish, where the interaction was previously carried out directly (face to face), now a person has more interaction or communication using only the gadgets. This is because there are many things that can be done by users without the need to move from one place to another, including in terms of communication (8).

This is supported by the theory that online games have an impact on the bad social adjustment. The poor social adjustment has an impact on the disruption of psychological and social functions and the disruption of people's relationships with their environment. Social adjustment is bad because individuals fail to deal with the conflicts they face or do not find appropriate ways to overcome problems or guidance from the environment, causing a lot of emotional turmoil, as well as frustrating conflict. Someone who is addicted to online games, his mind continues to focus on online games, feeling anxious when not playing it. Someone who is addicted to online games feels cool and continues to add time to playing online games.

\section{Conclusion and Suggestion}

To sum up, game online will influence the social interaction of juvenile at SMK Gunung Sari 1 Makassar. The risk is $68.9 \%$ (six times) with $\mathrm{p}=0.000$

\section{References}

1. Kursiwi. Dampak Penggunaan Gadget Terhadap Interaksi Sosial Mahasiswa Semester V (Lima) Jurusan Pendidikan IPS Fakultas Ilmu Tarbiyah dan Keguruan (FITK) UIN Syarif Hidayatulah Jakarta. [Jakarta]: UIN Syarif Hidayatullah; 2016.

2. Fauzi MP. Hampir 5 Miliar Orang di Dunia Gunakan Gadget: Okezone techno [Internet]. https://techno.okezone.com/. 2017 [cited 2018 Apr 23]. Available from: https://techno.okezone.com/read/2017/06/19/207/1720068/hampir-5-miliar-orang-di-duniagunakan-gadget

3. Hestya LK. 58\% Pengguna Smartphone Dari Kalangan Remaja [Internet]. Telset. 2012. Available from: https://telset.id/51928/58-pengguna-smartphone-dari-kalangan-remaja/

4. Wahyudi A. Indonesia Asian Digital Technology Giant [Internet]. 2017 [cited 2018 Apr 18]. Available from: https://databoks.katadata.co.id/datablog/2017/01/24/indonesia-raksasa-teknologi-digitalasia

5. Asif RA, Rahmadi AF. Relationship to the level of addiction to gadgets withInterference. 2017.

6. Lestari I, Riana AW, Taftazani BM. Pengaruh Gadget Pada Interaksi Sosial Dalam Keluarga. Prosiding Penelitian dan Pengabdian kepada Masyarakat [Internet]. 2015 Oct 1 [cited 2019 Dec 5];2(2). Available from: http://jurnal.unpad.ac.id/prosiding/article/view/13280

7. Santoso YRD, Purnomo JT. Hubungan Kecanduan Game Online Terhadap Penyesuaian Sosial Pada Remaja. Jurnal Humaniora Yayasan Bina Darma. 2017;4(1):027-44.

8. Indriani N, Musdalifah. Pengaruh Intensitas Penggunaan Smartphone Terhadap Interaksi Sosial Mahasiswa Politeknik Negeri Samarinda. 2017;4. 